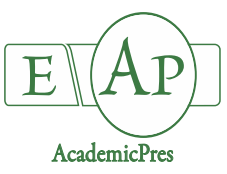

Shakoor A et al. (2021)

Notulae Botanicae Horti Agrobotanici Cluj-Napoca

Volume 49, Issue 1, Article number 12153

DOI: $10.15835 /$ nbha49112153

Research Article

\title{
Morphometric analysis and sequence related amplified polymorphism determine genetic diversity in Salvia species
}

\author{
Abdul SHAKOOR ${ }^{1,2}$, Fang ZHAO ${ }^{1,2 *}$, Gul ZAIB ${ }^{3,4}$, Wuyang $\mathrm{LI}^{1}$, \\ Xincan LAN ${ }^{1}$, Somayeh ESFANDANI-BOZCHALOYI ${ }^{5}$ \\ ${ }^{1}$ Henan University, College of Environment and Planning, Kaifeng, 475004, Henan, China; abdul_shakoor954@yahoo.com; \\ zhaofang@Ireis.ac.cn (corresponding author);104753190127@henu.edu.cn; Lxc0113@henu.edu.cn \\ ${ }^{2}$ Key Laboratory of Geospatial Technology for the Middle and Lower Yellow River Regions, Ministry of Education, Kaifeng 475004, \\ Henan, China \\ ${ }^{3}$ Yangzhou University, Institute of Epigenetics and Epigenomics, Yangzhou, China; gulzaib_ehsan@hotmail.com; \\ ${ }^{4}$ Yangzhou University, College of Veterinary Sciences, Yangzhou, China \\ ${ }^{5}$ Shahid Beheshti University, Faculty of Life Sciences and Biotechnology, Department of Plant Sciences, Tehran, \\ Iran;somayehesfand@yahoo.com
}

\begin{abstract}
Salvia species is a member of the Lamiaceae family, and it also possesses medicinal and horticulture values. The genetic diversity was assessed through sequence-related amplified polymorphism. To uncover genetic diversity and species characteristics in Salvia species were studied through a combination of morphological and molecular data. One hundred forty-five individuals related to 30 Salvia were collected in 18 provinces. A total of 157 (Number of total loci) (NTL) DNA bands were produced through polymerase chain reaction (PCR) from 30 Salvia species. These bands were produced with the combinations of 10 selective primers. The total number of amplified fragments ranged from 10 to 20 . The predicted unbiased heterozygosity $(\mathrm{H})$ varied between 0.11 (Salvia urmiensis) and 0.31 (Salvia limbata). High Shannon's information index was detected in Salvia limbata. The genetic similarities between 30 species are estimated from 0.46 to 0.91 . Clustering results showed two major clusters. According to the SRAP (Sequence-related amplified polymorphism) markers analysis, Salvia hydrangea and Salvia sharifii had the lowest similarity. Salvia bracteata and Salvia suffruticosa were genetically dissimilar to each other. This study also detected a significant signature of isolation by distance. Present results showed that sequence-related amplified polymorphism has the potential to decipher genetic affinity between Salvia species. Current results have implications in biodiversity and conservation programs. Besides this, present results could pave the way for selecting suitable ecotypes for forage and pasture purposes in Iran.
\end{abstract}

Keywords: gene flow; labiatae; morphometric analysis; Salvia; sequence-related polymorphism

\section{Introduction}

Salvia species is a member of the Lamiaceae family, and the high diversity of Salvia L. has been reported in Western Asia, Eastern Asia, and South America (Walker et al., 2004). Iran is considered one of Salvia's

Received: 11 Nov 2020. Received in revised form: 18 Dec 2020. Accepted: 12 Jan 2021. Published online: 14 Jan 2021.

From Volume 49, Issue 1, 2021, Notulae Botanicae Horti Agrobotanici Cluj-Napoca journal will use article numbers in place of the traditional method of continuous pagination through the volume. The journal will continue to appear quarterly, as before, with four annual numbers. 
important regions, and 19 species are endemic to Iran (Jamzad, 2013). The majority of species are aromatic and possess medicinal and horticultural values (Safaei et al., 2016). Some of the Salvia species are also pharmacologically important and possess anti-inflammatory (Hosseinzadeh et al., 2003) and gastro-protective properties (Mayer et al., 2009). Scientific data shows that member of Salvia species, such as Salvia miltiorrhiza, is widely used in folk and traditional medicine and used in cardiovascular treatment (Wang et al., 2009).

Several systematics and genetic diversity studies were carried out via molecular markers to address population structure, genetic diversity, and phylogenetic relations between the species (Robarts and Wolfe, 2014). Some experiments have been performed to determine genetic diversity within the Salviagenus (Song et al., 2010; Erbano et al., 2015). In the past, molecular methods such as Inter Simple Sequence Repeats (ISSR) and Random Amplification Polymorphic DNA (RAPD) have been used to study genetic diversity in Salvia (Song et al., 2010; Javan et al., 2012; Peng et al., 2014; Erbano et al., 2015). Sequence-related amplified polymorphism (SRAP) is PCR -based marker system. It is an efficient and simple marker system to study gene mapping and gene tagging in plant species ( $\mathrm{Li}$ and Quiros, 2001). SRAP are potential markers to assess plant systematics and genetic diversity studies (Robarts and Wolfe, 2014). Previously, Wu et al. (2010) assessed genetic diversity and population structure in Pogostemon cablin with SRAP markers' aid. SRAP markers were successfully implemented in Lamiaceae family to study natural populations and variations within the family (Saebnazar and Rahmani, 2013; Talebi et al., 2015). These past studies showed that molecular markers, including SRAP markers, are efficient in investigating genetic diversity analyses and the phylogenetic relationship among Salvia species in the Lamiaceae family. Indeed, molecular markers are efficient methods to study genetic diversity (Esfandani-Bozchaloyi and Sheidai, 2018). Genetic diversity helps plant species to survive and adapt against constantly changing environmental conditions (Pauls et al., 2013).

In order to develop conservation strategies and proper utilization of plant genetic resources, it is crucial to characterize plant species based on genetic studies (Kharazian et al., 2015), particularly this approach may assist in understanding genotypes of the geographically differentiated genus, such as Salvia (Song et al., 2010; Erbano et al., 2015). In Iran, most of the studies have been conducted to assess the medicinal potential of the Salvia species. The majority of the studies have addressed phytochemical and antimicrobial aspects. Therefore, we implemented the morphometric analysis and Sequence related amplified polymorphism to study genetic diversity. According to current knowledge, this is the first study that successfully documented genetic diversity based on novel sequence-related amplified polymorphism markers.

The present study investigated the molecular variation of 30 Salvia species in Iran. The study's objectives were: estimate genetic diversity; evaluate population relationships using WARD approaches. Current results have implications in breeding and conservation programs.

\section{Materials and Methods}

\section{Plants collection}

One hundred forty-five (145) individuals of Salvia were sampled. These individuals were recorded based on eco-geographical different features. Thirty Salvia species in East Azerbaijan, Lorestan, Kermanshah, Guilan, Mazandaran, Golestan, Yazd, Esfahan, Tehran, Arak, Hamadan, Kurdistan, Ilam, Bandar Abbas, Ghazvin, Khorasan, and Ardabil Provinces of Iran were selected and sampled during July-August 2017-2019 (Table 1). Morphometric and SRAP analyses on 145 plant accessions were carried out. One to twelve samples from each population belonging to 30 different species were selected based on other eco-geographic characteristics. Samples were stored at $-20^{\circ} \mathrm{C}$ till further use. Detailed information about samples locations and geographical distribution of species are mentioned (Table 1 and Figure 1). 
Shakoor A et al. (2021). Not Bot Horti Agrobo 49(1):12153

Table 1. Locality and geographical information of Salvia species

\begin{tabular}{|c|c|c|c|c|c|}
\hline No. & Species names & Locations & Latitude & Longitude & Altitude \\
\hline Sp1 & $\begin{array}{c}\text { Salvia aristata } \\
\text { Aucher ex Benth. }\end{array}$ & East Azerbaijan, Kaleybar, Shojabad & $38^{\circ} 52^{\prime} 37^{\prime \prime}$ & $47^{\circ} 23^{\prime} 92^{\prime \prime}$ & 1144 \\
\hline $\mathrm{Sp} 2$ & S.eremophila Boiss. & Esfahan, Ghameshlou, Sanjab & $32^{\circ} 50^{\prime \prime} 03^{\prime \prime}$ & $51^{\circ} 24^{\prime} 28^{\prime \prime}$ & 1990 \\
\hline Sp3 & S. santolinifolia Boiss. & Fars, Jahrom & $29 \circ 20^{\prime} 07^{\prime \prime \prime}$ & $51^{\circ} 52^{\prime} 08^{\prime \prime}$ & 1610 \\
\hline $\mathrm{Sp} 4$ & S. tebesana Bunge & Khorasan, Tabas & $29 \circ 20^{\prime} 07^{\prime \prime \prime}$ & $51^{\circ} 52^{\prime} 08^{\prime \prime}$ & 220 \\
\hline Sp5 & S. bracteata Banks \& Sol & $\begin{array}{c}\text { Lorestan, Oshtorankuh, above Tihun } \\
\text { village }\end{array}$ & $33^{\circ} 57^{\prime} 12^{\prime \prime}$ & $47^{\circ} 57^{\prime} 32^{\prime \prime}$ & 2500 \\
\hline Sp6 & $\begin{array}{l}\text { S. suffruticosa Montb. \& } \\
\text { Aucher }\end{array}$ & Hamedan, Nahavand & $34^{\circ} 52^{\prime} 373$ & $48^{\circ} 23^{\prime} 92^{\prime \prime}$ & 2200 \\
\hline Sp7 & S.dracocephaloides Boiss. & $\begin{array}{c}\text { East Azerbaijan, Kaleybar, Cheshme Ali } \\
\text { Akbar }\end{array}$ & $38^{\circ} 52^{\prime} 373$ & $47^{\circ} 23^{\prime} 92^{\prime \prime}$ & 1144 \\
\hline Sp8 & S. hydrangea DC. ex Benth. & $\begin{array}{c}\text { Arak, Komayjan, Pass of Chehregan } \\
\text { village, the margin road }\end{array}$ & $35^{\circ} 50^{\prime} 03^{\prime \prime}$ & $51^{\circ} 24^{\prime} 28^{\prime \prime}$ & 1700 \\
\hline Sp9 & S. multicaulis Vahl. & $\begin{array}{c}\text { Mazandaran, Haraz road, Emam Zad-e- } \\
\text { Hashem }\end{array}$ & $36^{\circ} 14^{\prime} 14^{\prime \prime}$ & $51^{\circ} 18^{\prime} 07^{\prime \prime}$ & 1807 \\
\hline Sp10 & S. syriaca L. & Esfahan, Fereydunshahr & $32 \circ 36^{\prime} 93^{\prime \prime}$ & $51^{\circ} 27^{\prime} 90^{\prime \prime}$ & 2500 \\
\hline Sp11 & S. viridis $\mathrm{L}$. & Guilan, Sangar, Roadside & $37^{\circ} 07^{\prime} 02^{\prime \prime}$ & $49^{\circ} 44^{\prime} 32^{\prime \prime}$ & 48 \\
\hline Sp12 & $\begin{array}{l}\text { S. mirzayanii Rech. f. \& } \\
\text { Esfand. }\end{array}$ & Boushehr, Dashtestan & $28^{\circ} 57^{\prime} 22^{\prime \prime}$ & $51^{\circ} 28^{\prime} 31^{\prime \prime}$ & 430 \\
\hline Sp13 & S. macrosiphon Boiss. & Yazd, Khatam & $30 \circ 07^{\prime} 24^{\prime \prime}$ & $53^{\circ} 59^{\prime} 06^{\prime \prime}$ & 2178 \\
\hline Sp14 & S. sharifii Rech. f. \& Esfand. & Bandar Abbas, Hormozgan & $28^{\circ} 57^{\prime} 22^{\prime \prime}$ & $51^{\circ} 28^{\prime} 31^{\prime \prime}$ & 288 \\
\hline Sp15 & S. reuterana Boiss. & Hamedan, Alvand & $34^{\circ} 46^{\prime} 10^{\prime \prime}$ & $48^{\circ} 30^{\prime} 00^{\prime \prime}$ & 1870 \\
\hline Sp16 & S. palaestina Benth. & Kermanshah, Islamabad & $35^{\circ} 37^{\prime} 77^{\prime \prime}$ & $46^{\circ} 20^{\prime} 25^{\prime \prime}$ & 1888 \\
\hline Sp17 & $\begin{array}{l}\text { S. sclareopsis Bornm. ex } \\
\text { Hedge }\end{array}$ & Ilam, Ilam & $33^{\circ} 47^{\prime} 60^{\prime \prime}$ & $46^{\circ} 07^{\prime} 58^{\prime \prime}$ & 1250 \\
\hline Sp18 & S. spinose L. & Guilan, Lahijan & $37^{\circ} 07^{\prime} 02^{\prime \prime}$ & $49^{\circ} 44^{\prime} 32^{\prime \prime}$ & 48 \\
\hline Sp19 & S. compressa Vent. & Bandar Abbas, Hormozgan & $28^{\circ} 57^{\prime} 22^{\prime \prime}$ & $51^{\circ} 28^{\prime} 31^{\prime \prime}$ & 288 \\
\hline Sp20 & S. sclarea L. & Esfahan, Ghameshlou, Sanjab & $32 \circ 36^{\prime} 93^{\prime \prime}$ & $51^{\circ} 27^{\prime} 90^{\prime \prime}$ & 2500 \\
\hline Sp21 & S. aethiopis L. & $\begin{array}{c}\text { Azerbaijan, } 78 \mathrm{~km} \text { from Mianeh to } \\
\text { Khalkhl. }\end{array}$ & 37॰38_53 & $48 \circ 36 \_11$ & 1500 \\
\hline Sp22 & S. microstegia Boiss. \& Bal. & Tehran, Darband & $35^{\circ} 36^{\prime} 93^{\prime \prime}$ & $51^{\circ} 27^{\prime} 90^{\prime \prime}$ & 1700 \\
\hline Sp23 & $\begin{array}{l}\text { S. xanthocheila Boiss. ex } \\
\text { Benth. }\end{array}$ & Ardabil, Khalkhal & $37 \circ 38 \_53$ & $48 \circ 36 \_11$ & 1958 \\
\hline Sp24 & S. limbata C.A. Mey. & Guilan,Gole rodbar, Road side & $37^{\circ} 09^{\prime} 45^{\prime \prime}$ & $49^{\circ} 55^{\prime} 39^{\prime \prime}$ & 15 \\
\hline Sp25 & $\begin{array}{l}\text { S. chloroleuca Rech. f. \& } \\
\text { Aell. }\end{array}$ & Golestan, Ramian & $37^{\circ} 09^{\prime} 45^{\prime \prime}$ & $55^{\circ} 55^{\prime} 39^{\prime \prime}$ & 1320 \\
\hline Sp26 & S. virgate Jacq. & Golestan, Ramian & $37^{\circ} 09^{\prime} 45^{\prime \prime}$ & $55^{\circ} 55^{\prime} 39^{\prime \prime}$ & 1320 \\
\hline Sp27 & S. nemorosa L. & Mazandaran, Chalos & $36^{\circ} 14^{\prime} 14^{\prime \prime}$ & $51^{\circ} 18^{\prime} 07^{\prime \prime}$ & 1807 \\
\hline Sp28 & S. urmiensis Bunge & Kurdistan, Sanandaj & $37^{\circ} 09^{\prime} 45^{\prime \prime}$ & $55^{\circ} 55^{\prime} 39^{\prime \prime}$ & 1320 \\
\hline Sp29 & $\begin{array}{l}\text { S. oligphylla Aucher ex } \\
\text { Benth. }\end{array}$ & Ghazvin to Hamedan just after Avaj & $35^{\circ} 36^{\prime} 93^{\prime \prime}$ & $51^{\circ} 27^{\prime} 90^{\prime \prime}$ & 2100 \\
\hline Sp30 & S. verticillata $\mathrm{L}$. & Mazandaran Jadeh Chalous & $36^{\circ} 14^{\prime} 14^{\prime \prime}$ & $51^{\circ} 18^{\prime} 07^{\prime \prime}$ & 1807 \\
\hline
\end{tabular}




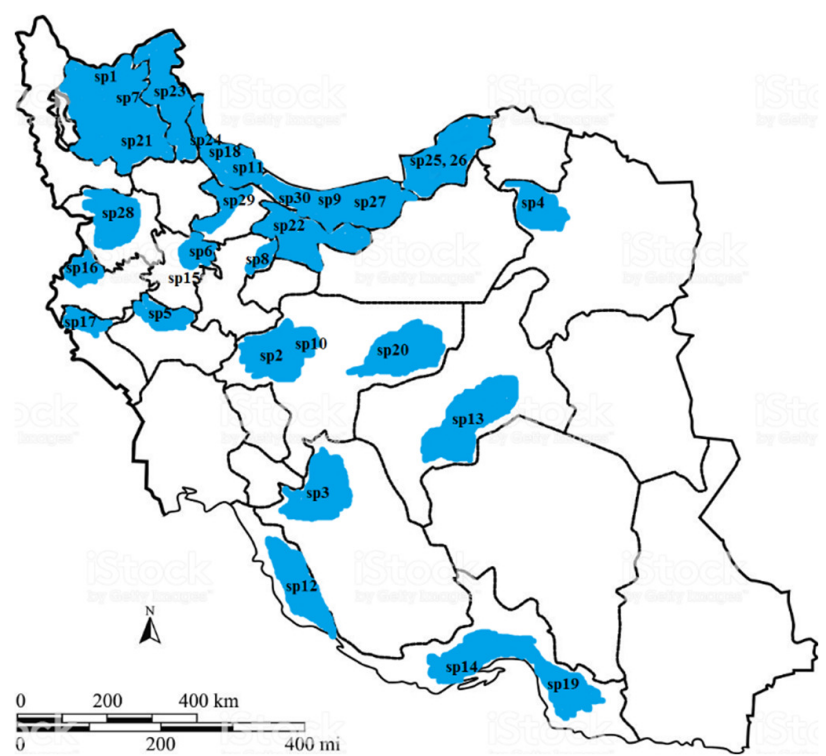

Figure 1. Provinces and collection sites of Salvia, Iran $\mathrm{sp} 1=$ Salvia aristata; $\mathrm{sp} 2=S$. eremophila; $\mathrm{sp} 3=S$. santolinifolia; $\mathrm{sp} 4=S$. tebesana; $\mathrm{sp} 5=S$. bracteata $; \mathrm{sp} 6=S$. suffruticosa; $\mathrm{sp} 7=$ S. dracocephaloides; $\mathrm{sp} 8=$ S. hydrangea; $\mathrm{sp} 9=$ S. multicaulis; $\mathrm{sp10}$ : S. syriaca; sp11: S. viridis; $\mathrm{sp12=}$ S. mirzayanii; $\mathrm{sp} 13=$ S. macrosiphon $; \mathrm{sp} 14=$ S. sharifii; $\mathrm{sp} 15=$ S. reuterana $; \mathrm{sp} 16=$ S. palaestina $; \mathrm{sp} 17=$ S. sclareopsis; $\mathrm{sp} 18=S$. spinose $; \mathrm{sp} 19=S$. compressa; $\mathrm{sp} 20=S$. sclarea; $\mathrm{sp} 21=S$. aethiopis; $\mathrm{sp} 22=$ S. microstegia $; \mathrm{sp} 23=S$. xanthocheila; $\mathrm{sp} 24=$ S. limbata; $\mathrm{sp} 25=$ S. chloroleuca; $\mathrm{sp} 26=$ S. virgate; $\mathrm{sp} 27=$ S. nemorosa $; \mathrm{sp} 28=$ S. urmiensis; $\mathrm{sp} 29=$ S. oligphylla; $\mathrm{sp} 30=S$. verticillata

\section{Morphological studies}

Each species was subjected to morphometric analysis, and twelve samples per species were processed. Qualitative (9) and quantitative (13) morphological characters were studied. Data were transformed before calculation. Different morphological characters of flowers, leaves, and seeds were studied. Ordination analyses were conducted while using Euclidean distance (Podani, 2000).

\section{Sequence-related amplified polymorphism method}

Fresh leaves from one to twelve plants, were randomly used. These were dried with silica gel powder. Genomic DNA was extracted while following the previous protocol (Esfandani-Bozchaloyi et al., 2019). SRAP assay was performed as described previously ( $\mathrm{Li}$ and Quiros, 2001). Ten SRAP in different primer combinations (PCs) were used. A $25 \mu \mathrm{l}$ volume containing ten $\mathrm{mM}$ of Tris- $\mathrm{HCl}$ buffer at $\mathrm{pH} 8 ; 50 \mathrm{mM}$ of $\mathrm{KCl}$; $1.5 \mathrm{mM}$ of MgCl2; $0.2 \mathrm{mM}$ of each dNTP (Bioron, Germany); $0.2 \mu \mathrm{M}$ of single primer; $20 \mathrm{ng}$ of genomic DNA and $3 \mathrm{U}$ of Taq DNA polymerase (Bioron, Germany) were subjected to PCR reactions. The overall reaction volume consisted of $25 \mu \mathrm{l}$. For the PCR reaction, the Techne thermocycler (Germany) was used. In the initial denaturation step, the temperature was kept at $94^{\circ} \mathrm{C}$ for 5 minutes. It was followed by 40 cycles for 1 minute at $94^{\circ} \mathrm{C}, 1$ minute at $52-57^{\circ} \mathrm{C}$, and 2 minutes at $72^{\circ} \mathrm{C}$. In the final extension step, the cycle duration was kept $7-10 \mathrm{~min}$ at $72^{\circ} \mathrm{C}$. Staining was performed with the aid of ethidium bromide. DNA bands/fragments were compared against a $100 \mathrm{bp}$ molecular size ladder (Fermentas, Germany).

\section{Data analyses}

In the current study, the UPGMA (Unweighted paired group using average) ordination method was implemented to assess morphological characters. ANOVA (Analysis of variance) was conducted to assess morphological differences among species. Principle coordinates analysis (PCoA) was implemented to identify variable morphological characters in Salvia species. Multivariate statistical analyses, i.e., PCoA analysis, were performed in PAST software version 2.17 (Hammer et al., 2001). 


\section{Molecular analyses}

Sequence-related amplified polymorphism (SRAP) bands were recorded. These brands' presence and absence were scored based on the present (1) and absent (0). Total loci (NTL) and the number of polymorphism loci (NPL) for each primer were calculated. Furthermore, the polymorphic ratio was assessed based on NPL/NTL values. Polymorphism information content was calculated as previously suggested by Roldan-Ruiz et al. (2000). Resolving power for individual marker system was calculated as $\mathrm{Rp}=\Sigma \mathrm{Ib}$. Ib (band informativeness) was estimated while following equation: proposed as: $\mathrm{Ib}=1-[2 \mathrm{x}(0.5-\mathrm{p})]$. In the equation, $\mathrm{p}$ indicates the presence of bands (Prevost and Wilkinson, 1999). The pairwise genetic similarity of the marker system was evaluated (Jaccard, 1908). Unbiased expected heterozygosity and Shannon information index were calculated in GenAlEx 6.4 software (Peakall and Smouse, 2006). Gene flow was conducted in POPGENE software, version 1.32 (Yeh et al., 1999). Analysis of molecular variance test was conducted in GenAlEx (Peakall and Smouse, 2006). Mantel test was performed with 5000 permutations in the PAST, version 2.17 (Hammer et al., 2001).

\section{Results}

\section{Morphometry}

The ANOVA findings showed substantial differences $(\mathrm{p}<0.01)$ between the species in terms of quantitative morphological characteristics. Principle coordinates analysis results explained $67 \%$ cumulative variation. The first PCoA axis explained $53 \%$ of the total variation. The correlation $(>0.7)$ was shown by morphological characters such as seed form, calyx shape, calyx length, bract length, and basal leaf shape. The morphological characters of Salvia species are shown in the PCoA plot (Figure 2). Each species formed separate groups based on morphological characters. The morphometric analysis showed a clear difference among Salvia species and separated each group.

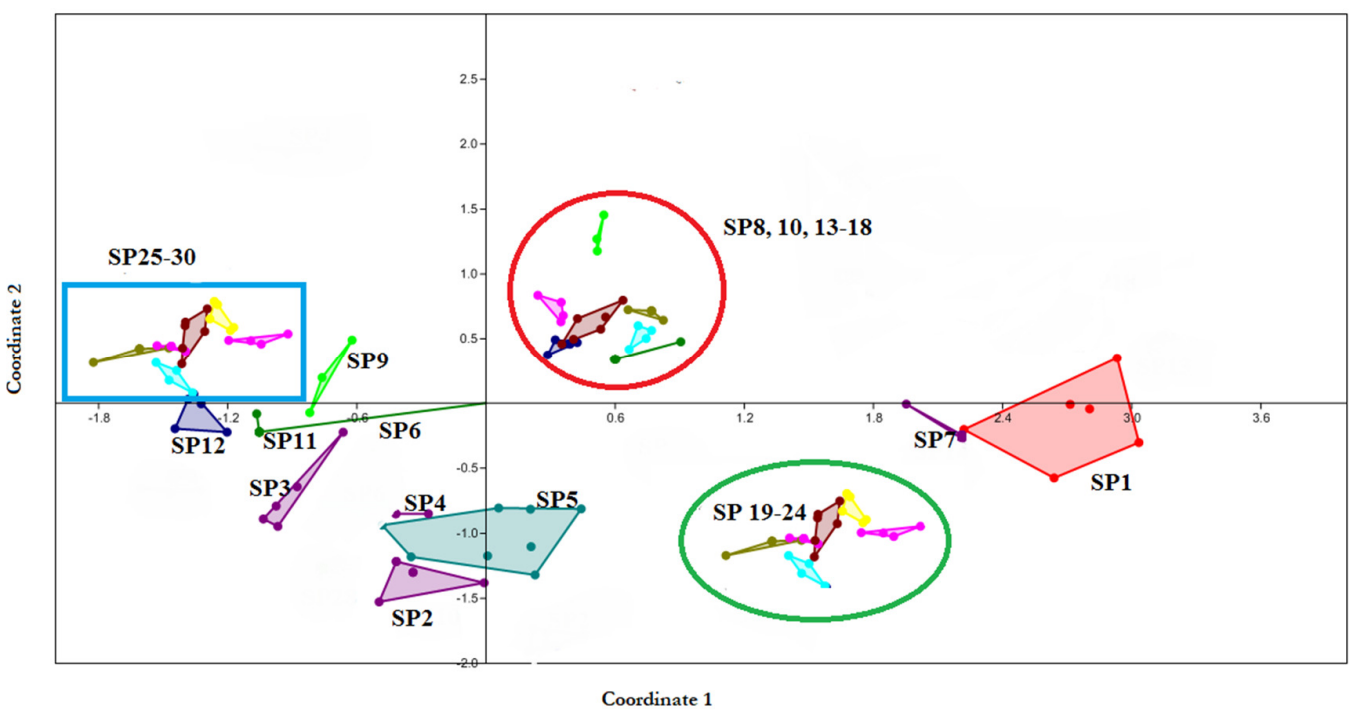

Figure 2. Morphological characters analysis of Salvia species by PCoA $\mathrm{sp} 1=$ Salvia aristata; $\mathrm{sp} 2=S$. eremophila $; \mathrm{sp} 3=S$. santolinifolia; $\mathrm{sp} 4=$ S. tebesana; $\mathrm{sp} 5=$ S. bracteata $; \mathrm{sp} 6=S$. suffruticosa; $\mathrm{sp} 7=$ S. dracocephaloides; $\mathrm{sp} 8=$ S. hydrangea $\mathrm{sp} 9=$ S. multicaulis, $\mathrm{sp} 10:$ S. syriaca; $\mathrm{sp11:}$ S. viridis; $\mathrm{sp12=}$ S. mirzayanii; $\mathrm{sp} 13=$ S. macrosiphon $; \mathrm{sp} 14=$ S. sharifii $; \mathrm{sp} 15=$ S. reuterana; $\mathrm{sp} 16=$ S. palaestina $; \mathrm{sp} 17=$ S. sclareopsis; $\mathrm{sp} 18=S$. spinose; $\mathrm{sp} 19=S$. compressa; $\mathrm{sp} 20=S$. sclarea; $\mathrm{sp} 21=S$. aethiopis; $\mathrm{sp} 22=$ S. microstegia; $\mathrm{sp} 23=S$. xanthocheila; $\mathrm{sp} 24=$ S. limbata; $\mathrm{sp} 25=$ S. chloroleuca; $\mathrm{sp} 26=$ S. virgate; $\mathrm{sp} 27=$ S. nemorosa $; \mathrm{sp} 28=$ S. urmiensis; $\mathrm{sp} 29=$ S. oligphylla; $\mathrm{sp} 30=S$. verticillata 


\section{Species identification and genetic diversity}

Ten (10) suitable primer combinations (PCs) were screened out of 25 PCs in this research. Figure 3 illustrates the banding pattern of Em4-Mel primer by the SRAP marker profile. One hundred and forty-four (144) amplified polymorphic bands (number of polymorphic loci) were produced. These bands (fragments) had different ranges i.e., $100 \mathrm{bp}$ to $3000 \mathrm{bp}$. Maximum and minimum numbers of polymorphic bands were 20 and 10 for Em2-Me5 and 10 Em1-Me1, respectively. Each primer produced 14.4 polymorphic bands on average. The PIC ranged from 0.35 (Em2-Me5) to 0.51 (Em1-Me1) for the 10 SRAP primers, with an average of 0.45 per primer. The resolving power (Rp) of the primers ranged from 22.87 (Em2-Me2) to 44.23 (Em1Me4), with an average of 35.98 per primer (Figure 3, Table 2).

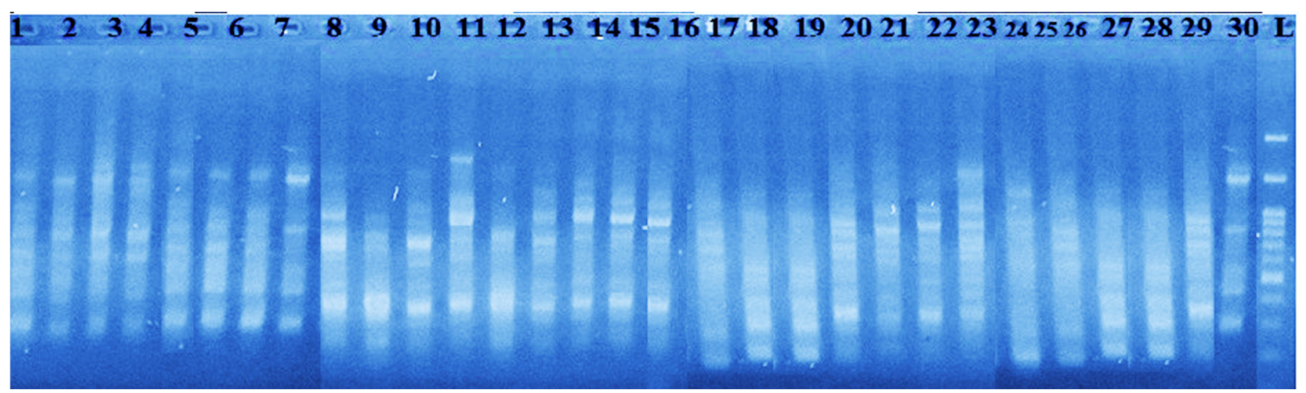

Figure 3. Electrophoresis gel of studied ecotypes from DNA fragments produced by SRAP profile based on Em4-Me1primer

$1=$ Salvia aristata; $2=$ S. eremophila; $3=$ S. santolinifolia; $4=S$. tebesana $; 5=S$. bracteata $; 6=$ S. suffruticosa $7=S$. dracocephaloides; $8=S$. hydrangea; $9=S$. multicaulis; $10: S$. syriaca; $11: S$. viridis; $12=S$. mirzayanii; $13=S$. macrosiphon; $14=$ S. sharifii $; 15=$ S. reuterana; $16=$ S. palaestina; $17=$ S. sclareopsis; $18=$ S. spinose; $19=$ S. compressa; $20=S$. sclarea; $21=S$. aethiopis $; 22=S$. microstegia $; 23=S$. xanthocheila $24=S$. limbata $25=$ S. chloroleuca $; 26=S$. virgate; $27=$ S. nemorosa; $28=$ S. urmiensis $29=$ S. oligphylla $; 30=$ S. verticillata $\mathrm{L}=$ Ladder $100 \mathrm{bp}$.

Table 2. SRAP primer information and results

\begin{tabular}{|c|c|c|c|c|c|}
\hline Primer name & NTL $^{\mathrm{a}}$ & NPL $^{\mathrm{b}}$ & $\mathrm{P}^{\mathrm{c}}$ & $\mathrm{PIC}^{\mathrm{d}}$ & $\mathrm{RP}^{\mathrm{e}}$ \\
\hline Em1-Me1 & 10 & 10 & $100.00 \%$ & 0.51 & 32.24 \\
\hline Em2-Me2 & 24 & 19 & $79.00 \%$ & 0.48 & 22.87 \\
\hline Em1-Me4 & 11 & 11 & $100.00 \%$ & 0.44 & 44.23 \\
\hline Em2-Me4 & 16 & 16 & $100.00 \%$ & 0.47 & 38.55 \\
\hline Em2-Me5 & 20 & 20 & $100.00 \%$ & 0.35 & 39.65 \\
\hline Em3-Me4 & 18 & 12 & $67.00 \%$ & 0.48 & 43.55 \\
\hline Em3-Me1 & 13 & 12 & $92.31 \%$ & 0.44 & 36.77 \\
\hline Em4-Me1 & 12 & 12 & $100.00 \%$ & 0.42 & 40.46 \\
\hline Em5-Me1 & 18 & 17 & $94.4 \%$ & 0.43 & 33.76 \\
\hline Em5-Me2 & 15 & 15 & $100.00 \%$ & 0.49 & 35.98 \\
\hline Mean & 15.7 & 14.4 & $93.00 \%$ & 0.45 & 359.85 \\
\hline Total & 157 & 144 & & & \\
\hline
\end{tabular}

a: Number of total loci (NTL); b: Number of polymorphic loci (NPL); c: Polymorphic ratio (P \%); d: Polymorphic information content (PIC); e: Resolving power (Rp)

The calculated genetic parameters of Salvia species are shown (Table 3). The unbiased heterozygosity (H) varied between 0.11 (S. urmiensis) and 0.31 (S. limbata) with a mean of 0.20 . Shannon's information index (I) was maximum in $S$. limbata $(0.35)$, whereas we recorded minimum Shannon's information index in $S$. urmiensis (0.12). The observed number of alleles $(\mathrm{Na})$ ranged from $0.214 \mathrm{in} S$. compressa to 1.277 in $S$. verticillata. The significant number of alleles $(\mathrm{Ne})$ ranged from 1.00 (S. compressa) to 1.193 (S. verticillata). 
Table 3. Genetic diversity parameters

\begin{tabular}{|c|c|c|c|c|c|c|c|}
\hline SP & $\mathrm{N}$ & $\mathrm{Na}$ & $\mathrm{Ne}$ & I & $\mathrm{He}$ & $\mathrm{UHe}$ & $\mathrm{P} \%$ \\
\hline S. aristata & 5.000 & 0.336 & 1.034 & 0.23 & 0.25 & 0.19 & $51.83 \%$ \\
\hline S. eremophila & 4.000 & 0.344 & 1.042 & 0.20 & 0.23 & 0.20 & $57.53 \%$ \\
\hline S. santolinifolia & 5.000 & 0.369 & 1.011 & 0.15 & 0.28 & 0.22 & $42.15 \%$ \\
\hline S. tebesana & 8.000 & 0.566 & 1.014 & 0.25 & 0.20 & 0.21 & $37.58 \%$ \\
\hline S. bracteata & 9.000 & 0.432 & 1.049 & 0.18 & 0.22 & 0.25 & $55.05 \%$ \\
\hline S. suffruticosa & 8.000 & 0.313 & 1.026 & 0.144 & 0.13 & 0.26 & $49.23 \%$ \\
\hline S. dracocephaloides & 3.000 & 0.297 & 1.024 & 0.23 & 0.15 & 0.17 & $64.30 \%$ \\
\hline S. hydrangea & 9.000 & 0.352 & 1.083 & 0.23 & 0.22 & 0.14 & $45.05 \%$ \\
\hline S. multicaulis & 8.000 & 0.333 & 1.016 & 0.192 & 0.12 & 0.22 & $48.23 \%$ \\
\hline S. syriaca & 12.000 & 1.155 & 1.190 & 0.271 & 0.184 & 0.192 & $55.91 \%$ \\
\hline$S$. viridis & 5.000 & 0.358 & 1.440 & 0.174 & 0.30 & 0.29 & $66.50 \%$ \\
\hline S. mirzayanii & 6.000 & 0.299 & 1.029 & 0.231 & 0.18 & 0.23 & $44.38 \%$ \\
\hline S. macrosiphon & 5.000 & 0.462 & 1.095 & 0.288 & 0.25 & 0.22 & $62.05 \%$ \\
\hline S. sharifii & 5.000 & 0.358 & 1.117 & 0.28 & 0.15 & 0.12 & $44.30 \%$ \\
\hline S. reuterana & 8.000 & 0.399 & 1.167 & 0.259 & 0.234 & 0.193 & $39.88 \%$ \\
\hline S. palaestina & 6.000 & 0.892 & 1.138 & 0.221 & 0.141 & 0.165 & $38.63 \%$ \\
\hline S. sclareopsis & 6.000 & 0.244 & 1.032 & 0.26 & 0.23 & 0.18 & $55.53 \%$ \\
\hline S. spinose & 4.000 & 0.314 & 1.044 & 0.16 & 0.18 & 0.23 & $43.38 \%$ \\
\hline S. compressa & 8.000 & 0.288 & 1.00 & 0.33 & 0.17 & 0.12 & $42.23 \%$ \\
\hline S. sclarea & 5.000 & 0.341 & 1.058 & 0.24 & 0.27 & 0.20 & $53.75 \%$ \\
\hline S. aethiopis & 3.000 & 0.567 & 1.062 & 0.24 & 0.224 & 0.173 & $44.73 \%$ \\
\hline S. microstegia & 5.000 & 0.336 & 1.034 & 0.23 & 0.25 & 0.19 & $51.83 \%$ \\
\hline S.xanthocheila & 4.000 & 0.344 & 1.042 & 0.20 & 0.23 & 0.20 & $57.53 \%$ \\
\hline S. limbata & 5.000 & 0.358 & 1.440 & 0.35 & 0.35 & 0.31 & $69.50 \%$ \\
\hline S. chloroleuca & 10.000 & 0.431 & 1.088 & 0.33 & 0.22 & 0.13 & $57.53 \%$ \\
\hline S. virgata & 3.000 & 0.255 & 1.021 & 0.15 & 0.18 & 0.19 & $42.15 \%$ \\
\hline S. nemorosa & 3.000 & 0.288 & 1.024 & 0.23 & 0.15 & 0.17 & $64.30 \%$ \\
\hline S. urmiensis & 8.000 & 0.399 & 1.167 & 0.129 & 0.114 & 0.113 & $35.68 \%$ \\
\hline S. oligphylla & 8.000 & 0.333 & 1.016 & 0.172 & 0.12 & 0.22 & $48.23 \%$ \\
\hline S. verticillata & 12.000 & 1.277 & 1.193 & 0.271 & 0.184 & 0.192 & $55.91 \%$ \\
\hline
\end{tabular}

Abbreviations: ( $\mathrm{N}=$ number of samples, $\mathrm{Na}=$ number of different alleles; $\mathrm{Ne}=$ number of effective alleles, $\mathrm{I}=$ Shannon's information index, $\mathrm{He}=$ gene diversity, $\mathrm{UHe}=$ unbiased gene diversity, $\mathrm{P} \%=$ The percentage of polymorphism).

Analysis of molecular variance (AMOVA) results showed significant genetic difference $(p=0.01)$ among Salvia species. AMOVA findings revealed that $73 \%$ of the total variation was between species, and comparatively less genetic variation was recorded at the species level (Table 4). Genetic difference between Salvia species was highlighted by genetic statistics (Nei’s $\mathrm{G}_{\mathrm{ST}}$ ), as evident by significant $p$ values i.e. Nei’s $\mathrm{G}_{\mathrm{ST}}$ $(0.29, p=0.01)$ and D_est values $(0.167, p=0.01)$.

The constructed dendrogram highlighted two major clusters (Figure 4). Group A consisted of 8 species.Two sub-clusters were in the B group: eight species of S. multicaulis, S. syriaca; S. viridis, S. reuterana; S. palaestina; S. sclareopsis; S. spinose and S. oligphylla. 
Table 4. Molecular variance analysis

\begin{tabular}{|c|c|c|c|c|c|c|}
\hline Source & $\mathrm{df}$ & SS & MS & Est. Var. & $\%$ & $\Phi P T$ \\
\hline Among Pops & 27 & 1501.364 & 95.789 & 18.154 & $73 \%$ & \\
\cline { 1 - 5 } Within Pops & 139 & 334.443 & 3.905 & 2.888 & $27 \%$ & \multirow{2}{*}{$73 \%$} \\
\hline Total & 166 & 1955.807 & & 20.060 & $100 \%$ & \\
\hline
\end{tabular}

df: degree of freedom; SS: sum of squared observations; MS: mean of squared observations; EV: estimated variance; ФPT: proportion of the total genetic variance among individuals within an accession, $(P<0.001)$.

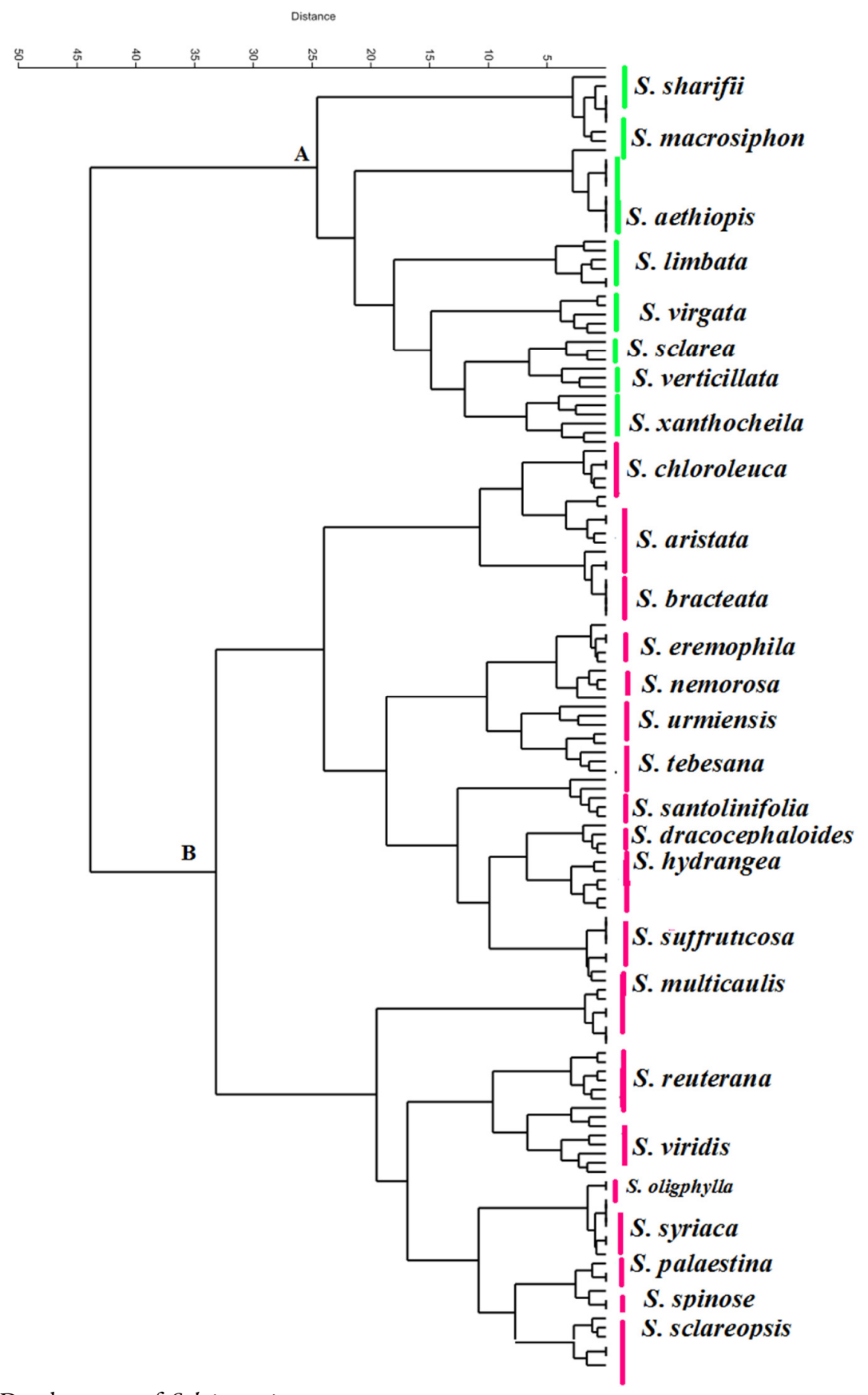

Figure 4. Dendrograms of Salvia species 
In the present study, a strong correlation between geographical and genetic distances $(r=0.19$, $p=0.0002)$ and a gene flow $\left(\mathrm{N}_{\mathrm{m})}\right.$ score of 0.287 was reported among species. Detailed information about genetic distances and genetic identity (Nei's) are described (Table S1, Supplementary Table). The findings suggested the significantly highest degree of genetic similarity $(0.91)$ between $S$. suffruticosa and $S$. bracteata. On the other hand, $S$. hydrangea and $S$. sharifii $(0.46)$ had the lowest genetic resemblance.

\section{Discussion}

We used morphological and molecular (SRAP) data to evaluate Salvia species relationships in the present study. Morphological analyses of Salvia species showed that quantitative indicators (ANOVA test results) and qualitative characteristics are well differentiated. PCoA analysis suggests that morphological characters such as bract length, stipule length, bract shape, calyx shape, petal shape, length have the potentials to identify and delimitate Salvia species. Multivariate statistical analysis results suggest the utilization of morphological characters to identify and delimitate Salvia Species. Morphological characters, comprising stipule length and petal shapes, play an important role in plant systematics and taxonomy. Our work also highlighted the significance of morphological characters and molecular data to identify and study species genetic diversity in Salvia species. Past research conducted on Salvia species has successfully linked morphological characters with molecular data to assess genetic diversity and species delimitation (Safaei et al., 2016). Current morphometric and molecular methods have been implemented to study genetic diversity in Salvia species. For instance, morphometric analysis, coupled with molecular markers, revealed genetic diversity in Salvia species (Radosavljevic et al., 2019). Genetic diversity is usually an important feature that helps plant species adapt to harsh environments (Tomasello et al., 2015). Current Salvia species showed high genetic diversity; therefore, it could be argued that Salvia species can withstand the changing environment. In general, genetic relationships obtained from SRAP data coincides with morphometric results. This finding is in accordance with the parameters of AMOVA and genetic diversity results. SRAP molecular markers detected apparent genetic differences among species. These results indicate that SRAP has the potentials to study plant systematics and taxonomy in Salvia members.

Given the negative impact of biodiversity threats and overexploitation of Salvia plant species in Iran, it is necessary to conduct genetic diversity studies on Salvia species. Genetic diversity-based studies pave our understanding to develop conservation strategies (Esfandani-Bozchaloyi et al., 2018). Genetic diversity studies are conducted through an appropriate selection of primers and indexes, including Polymorphic information content (PIC) and marker index (MI). These are important indexes and primers to fathom genetic variation in species (Sivaprakash et al., 2004). Common logic suggests that different makers have different abilities to assess genetic diversity, and usually, genetic diversity is linked with polymorphism (Sivaprakash et al., 2004). In this research, we reported PIC values of SRAP primers from 0.35 to 0.51 , with a mean value of 0.45 . PIC values indeed show low and high genetic diversity among genotypes. Values are ranging from zero to 0.25 show low genetic diversity; in contrast to this, 0.25 to 0.50 highlight mid-level of genetic diversity. In addition to this, values higher than 0.5 are associated with high genetic diversity (Tams et al., 2005). Present results highlighted the efficiency of SRAP markers to estimate genetic diversity in Salvia species. In our study, SRAP markers detected an average percentage of polymorphism (93\%). Current research results also described average PIC values of SRAP makers ( 0.45 ) and average RP (resolving power) values i.e. 35.98 of SRAP markers. These current reported values are higher than other reported markers on Salvia species (Wang et al., 2009; Song et al., 2010; Yousefiazar et al., 2016; Etminan et al., 2018). In the recent study, low gene flow $\left(N_{\mathrm{m}}\right)$ was detected among Salvia species. Despite the presence of limited gene flow in Salvia species, two distinct ecotypes were reported previously. These ecotypes were formed due to reproductive isolation caused by altitude gradients and different niches (Moein et al., 2019). The present study also depicted a significant correlation between genetic and geographical distances. Our findings revealed that isolation by distance (IBD) existed between Salvia 
species (Mantel test results). Several mechanisms, such as isolation, local adaptation, and genetic drift, shape the species or population differentiation (Frichot et al., 2013; De Kort et al., 2014). The magnitude of variability among $N \mathrm{a}, N e, H$, and $I$ indices demonstrated a high level of genetic diversity among Salvia species. Dendrogram and principal coordinates analysis results showed a clear difference among Salvia species. This result indicates the high utilization of the SRAP technique to identify Salvia species. Our results have implications for conservation and breeding programs. Furthermore, it may identify suitable ecotypes for forage and pasture.

\section{Conclusions}

The present study investigated the molecular variation of 30 species. The molecular and morphometric analysis confirmed the morphological and genetic differences among Salvia species. This study was the first attempt to assess genetic diversity through Sequence-related amplified polymorphism and morphometrics analysis in Iran. The current study reported two major clusters, and these two major groups were different from each other due to differences in morphological and genetic characters. The genetic similarities between 30 species were estimated from 0.46 to 0.91 . SRAP (Sequence-related amplified polymorphism) markers analysis showed that Salvia hydrangea and Salvia sharifii had the lowest similarity. The current study also reported the correlation between genetic and geographical distances, which indicated the isolation mechanism involved in the Salvia species ecology. Present results indicated the potential of sequence-related amplified polymorphism to assess genetic diversity and genetic affinity among Salvia species. Current results have implications in biodiversity and conservation programs. Besides this, present results could pave the way for selecting suitable ecotypes for forage and pasture purposes in Iran. Future studies might include other environmental variables, including soil chemistry and geology data, to disentangle the diversity and ecology of Salvia species. However, this study focused on genetic diversity while incorporating morphometric analysis and a novel SRAP marker system.

\section{Authors' Contributions}

A.S - Conceptualization, analyzed the data, mathematical processing, designed the study, prepared the initial draft; F.Z - Contributed to the conceptualization of ideas, the methodology, and the manuscripts' review, supervision, project administration, and funding acquisition. G.Z. - Genetic analysis, writing; curation, visualization, review, and editing; W.L - Literature review and contributed in mathematical processing, design; X.L - Contributed in the collection of data and analysis; S.E-B - Contributed in study design and reviewed the initial draft. All authors have read and agreed to the published version of the manuscript. All authors read and approved the final manuscript.

\section{Acknowledgements}

This work was funded by the National Natural Science Foundation of China (41601091) and integrated Scientific investigation of the North-South Transitional Zone of China (2017FY100900). We would also like to acknowledge the National Undergraduate Innovation and Entrepreneurship Training Program, Henan University (202010475126). Funders had no role in designing the experiments. 


\section{Conflict of Interests}

The authors declare that there are no conflicts of interest related to this article.

\section{References}

De Kort H, Vandepitte K, Mergeay J, Honnay O (2014). Isolation, characterization and genotyping of single nucleotide polymorphisms in the non-model tree species Frangula alnus (Rhamnaceae). Conservation Genetics Resources 6(2):267-269. https://doi.org/10.1007/s12686-013-0083-6

Erbano M, Schühli GSE, Santos, EPD (2015). Genetic variability and population structure of Salvia lachnostachys. implications for breeding and conservation programs. International Journal of Molecular Sciences 16(4)78397850. https://doi.org/10.3390/ijms16047839

Esfandani-Bozchaloyi S, Sheidai M (2018). Molecular diversity and genetic relationships among Geranium pusillum and G. pyrenaicum with inter simple sequence repeat (ISSR) regions. Caryologia 71(4):457-470. https://doi.org/10.1080/00087114.2018.1503500

Esfandani-Bozchaloyi S, Sheidai M, Kalalegh M (2019). Comparison of DNA extraction methods from Geranium (Geraniaceae). Acta Botanica Hungarica 61(3-4):251-266. https://doi.org/10.1556/034.61.2019.3-4.3

Esfandani-Bozchaloyi S, Sheidai M, Keshavarzi M, Noormohammadi Z (2018). Morphometric and ISSR-analysis of local populations of Geranium molle L. from the Southern Coast of the Caspian Sea. Cytology and Genetics 52(4):309321. https://doi.org/10.3103/S0095452718040102

Etminan A, Pour-Aboughadareh A, Noori A, Ahmadi-Rad A, Shooshtari L, Mahdavian Z, Yousefiazar-Khanian M (2018). Genetic relationships and diversity among wild Salvia accessions revealed by ISSR and SCoT markers. Biotechnology and Biotechnological 32(3):610-617. https://doi.org/10.1080/13102818.2018.1447397

Frichot E, Schoville SD, Bouchard G, François O (2013). Testing for Associations between loci and environmental gradients using latent factor mixed models. Molecular Biology and Evolution 30(7):1687-1699. https://doi.org/10.1093/molbev/mst063

Hammer O, Harper D, Ryan P (2001). PAST: Paleontological statistics software package for education and data analysis. Palaeontologia Electronica 4(1):1-9.

Hosseinzadeh H, Haddadkhodaparast MH, Arash AR (2003). Antinociceptive, anti-inflammatory and acute toxicity effects of Salvia leriifolia Benth seed extract in mice and rats. Phytotherapy Research 17(4):422-425. https://doi.org/10.1002/ptr.1154

Jaccard P (1908). Nouvelles recherches sur la distribution florale. Bulletin de la Societe Vaudoise des Sciences Naturelles 44(163):223-270. https://doi.org/10.5169/seals-268384

Jamzad Z (2013). A survey of Lamiaceae in the flora of Iran. Rostaniha 14(1):59-67. https://doi.org/10.22092/botany.2013.101317

Javan Z, Rahmani F, Heidari R (2012). Assessment of genetic variation of genus Salvia by RAPD and ISSR markers. Australian Journal of Crop Science 6(6):1068-107.

Kharazian N, Rahimi S, Shiran B (2015). Genetic diversity and morphological variability of fifteen Stachys (Lamiaceae) species from Iran using morphological and ISSR molecular markers. Biologia 70(4):438-452. https://doi.org/10.1515/biolog-2015-0051

Li G, Quiros CF (2001). Sequence-related amplified polymorphism (SRAP), a new marker system based on a simple PCR reaction: its application to mapping and gene tagging in Brassica. Theoretical and Applied Genetics 103(2):455461. https://doi.org/10.1007/s001220100570

Mayer B, Baggio CH, Freitas CS, dos Santos AC, Twardowschy A, Horst H, ... Marques MC (2009). Gastroprotective constituents of Salvia officinalis L. Fitoterapia 80(7):421-426. https://doi.org/10.1016/j.fitote.2009.05.015

Moein F, Jamzad Z, Rahiminejad M (2019). An integrating study of genetic diversity and ecological niche modelling in Salvia aristata (Lamiaceae). Acta Botanica Hungarica 61(1-2):185-204. https://doi.org/10.1556/034.61.2019.12.10

Pauls SU, Nowak C, Balint M, Pfenninger M (2013). The impact of global climate change on genetic diversity within populations and species. Molecular Ecology 22(4):925-946. https//doi.org/10.1111/mec.12152 
Peakall R, Smouse PE (2006). GENALEX 6: Genetic Analysis in Excel. Population genetic software for teaching and research. Molecular Ecology Notes 6(1):288-295. https://doi.org/10.1111/j.1471-8286.2005.01155.x

Peng L, Ru M, Wang B, Wang Y, Li B, Yu J, Liang Z (2014). Genetic diversity assessment of a germplasm collection of Salvia miltiorthiza Bunge. based on morphology, ISSR and SRAP markers. Biochemical Systematics and Ecology 55:84-92. https://doi.org/10.1016/j.bse.2014.01.020

Podani J (2000). Introduction to the exploration of multivariate data. Backhuyes, Leide, Netherlands.

Prevost A, Wilkinson MJ (1999). A new system of comparing PCR primers applied to ISSR fingerprinting of potato cultivars. Theoretical and Applied Genetics 98(1):107-112. https://doi.org/10.1007/s001220051046

Radosavljevic I, Bogdanovic S, Celep F, Filipovic M, Satovic Z, Surina B, Liber Z (2019). Morphological, genetic and epigenetic aspects of homoploid hybridization between Salvia officinalis L. and Salvia fruticosa Mill. Scientific Reports 9(1):3276. https://doi.org/10.1038/s41598-019-40080-0

Robarts DWH, Wolfe AD (2014). Sequence-related amplified polymorphism (SRAP) markers: A potential resource for studies in plant molecular biology. Applications in Plant Sciences 2(7):1400017. https://doi.org/10.3732/apps. 1400017

Roldán-Ruiz I, Dendauw J, Van Bockstaele E, Depicker A, De Loose M (2000). AFLP markers reveal high polymorphic rates in ryegrasses (Lolium spp.). Molecular Breeding 6(2):125-134. https://doi.org/10.1023/A:1009680614564

Saebnazar A, Rahmani F (2013). Genetic Variation Among Salvia Species Based on Sequence-Related Amplified Polymorphism (SRAP) Marker. Journal of Plant Physiology and Breeding 3(1):71-78.

Safaei M, Sheidai M, Alijanpour B, Noormohammadi Z (2016). Species delimitation and genetic diversity analysis in Salvia with the use of ISSR molecular markers. Acta Botanica Croatia 75(1):45-52. https://doi.org/10.1515/botcro-2016-0005

Sivaprakash KR, Prashanth SR, Mohanty BP, Parida A (2004). Genetic diversity of black gram (Vigna mungo) landraces as evaluated by amplified fragment length polymorphism markers. Current Science 86(10):1411-1416.

Song Z, Li X, Wang H, Wang J (2010). Genetic diversity and population structure of Salvia miltiorrhiza Bge in China revealed by ISSR and SRAP. Genetica 138(2):241-249. https://doi.org/10.1007/s10709-009-9416-5

Talebi M, Rahimmalek M, Norouzi M (2015). Genetic diversity of Thymus daenensis subsp. daenensis using SRAP markers. Biologia 70(4):453-459. https://doi.org/10.1515/biolog-2015-0059

Tams SH, Melchinger AE, Bauer E (2005). Genetic similarity among European winter triticale elite germplasms assessed with AFLP and comparisons with SSR and pedigree data. Plant Breeding 124(2):154-160. https://doi.org/10.1111/j.1439-0523.2004.01047.x

Tomasello S, Alvarez I, Vargas P, Oberprieler C (2015). Is the extremely rare Iberian endemic plant species Castrilanthemum debeauxii (Compositae, Anthemideae) a living fossil'? Evidence from a multi-locus species tree reconstruction. Molecular Phylogenetics and Evolution 82:118-130. https://doi.org/ 10.1016/j.ympev.2014.09.007

Walker JB, Sytsma KJ, Treutlein J, Wink M (2004). Salvia (Lamiaceae) is not monophyletic: implications for the systematics, radiation, and ecological specializations of Salvia and tribe Mentheae. American Journal of Botany 91(7):1115-1125. https://doi.org/10.3732/ajb.91.7.1115

Wang Q, Zhang B, Lu Q (2009). Conserved region amplification polymorphism (CoRAP), a novel marker technique for plant genotyping in Salvia miltiorrhiza. Plant Molecular Biology Reporter 27(2):139. https://doi.org/10.1007/s11105-008-0065-0

Wu Y-G, Guo Q-S., He J-C, Lin Y-F, Luo L-J, Liu G-D (2010). Genetic diversity analysis among and within populations of Pogostemon cablin from China with ISSR and SRAP markers. Biochemical Systematics and Ecology 38(1):6372. https://doi.org/10.1016/j.bse.2009.12.006

Yeh FC, Yang R, Boyle T (1999). POPGENE. Microsoft Windows-based freeware for population genetic analysis. Release 1.31. University of Alberta, pp 1-31.

Yousefiazar M, Asghari A, Ahmadi J, Asghari B, Jafari AA (2016). Genetic diversity of salvia species assessed by ISSR and rapd markers. Notulae Botanicae Horti Agrobotanici Cluj-Napoca 44(2):431-436. https://doi.org/10.15835/nbha44210579 
OPEN ACCESS

(c) (2)

The journal offers free, immediate, and unrestricted access to peer-reviewed research and scholarly work. Users are allowed to read, download, copy, distribute, print, search, or link to the full texts of the articles, or use them for any other lawful purpose, without asking prior permission from the publisher or the author.

License - Articles published in Notulae Botanicae Horti Agrobotanici Cluj-Napoca are Open-Access, distributed under the terms and conditions of the Creative Commons Attribution (CC BY 4.0) License. (C) Articles by the authors; UASVM, Cluj-Napoca, Romania. The journal allows the author(s) to hold the copyright/to retain publishing rights without restriction. 